\title{
BIOENERGETIKAI TECHNOLÓGIAI TRENDEK
}

\section{TRENDS IN BIOENERGY TECHNOLOGY}

\author{
Marosvölgyi Béla \\ DSc, professor emeritus, Soproni Egyetem, Kooperációs Kutatási Központ Nonprofit Kft. \\ marosvolgyi.b@gmail.com
}

\begin{abstract}
ÖSSZEFOGLALÁS
A biológiai energiahordozók felhasználásának minőségi és mennyiségi jellemzői és azok változásai trendekkel írhatók le. A fejlődési és fejlettségi szinteket természeti és társadalmi jellemzők befolyásolják.

A közelmúltban az energiatermelés ökonómiai jellemzői voltak a meghatározók, és az energiaárakban megjelenő gazdasági versenyeztetés volt a jellemző. A fosszilis energiahordozók újabb változatainak (palagáz, olajhomok, széntelepek stb.) feltárása és új technológiáik kifejlesztése hatására a fosszilis eredetű energiák árának csökkenését vagy stagnálását várták. Ugyanakkor a nemzetközi politikai folyamatok és a politikát alapvetően befolyásoló gazdasági erők hatására a fosszilis energiahordozók felhasználásának korábban tervezett csökkenése elmaradt.

Napjainkra az egyre növekvő energiaigény kielégítése már nemcsak az újabb energiahordozók feltárásával és használatbavételével jár együtt, hanem a fosszilis energiahordozók használata során felszabaduló szén-dioxid hatására a légkör $\mathrm{CO}_{2}$-tartalmának jelentős növekedése is mérhető. Ezzel a klímaváltozás megindulása, illetve a fotoszintézissel már nem kompenzálódó gyorsulása jár együtt. Korábban ezt a negatív tendenciát politikai okok és energetikai lobbik hatására igyekeztek tagadni, de az utóbbi időben megismert tudományos alapú bizonyítékok hatására bekövetkezhetett, hogy a klímaváltozást már nemzetközi politikai erők is elismerik.

A biomassza energetikai hasznosításával kapcsolatban korábban hangoztatott fő indok (a fosszilis energiahordozók készleteinek kimerülése) nem nyert bizonyítást, a fosszilis energiahordozók ára a lehetséges mértékben nem csökken, forrásai középtávon bővülnek, ugyanakkor a klímaváltozás várható hatásainak felismerése a nemzetközi szervezetek eddig példátlan összefogását eredményezte. Jelentős, a szén-dioxid-emisszió és a fosszilis energiahordozók felhasználásának mérséklésére irányuló megállapodások születtek, amelyek érvényesítésének határidői minden korábbinál közelebbiek, és a vállalt kötelezettségek nem teljesítőinél szankciók alkalmazása is számításba jöhet. Ezzel a bioenergetika új megvilágításba került, és kiemelt fejlesztésének tudományos és politikai alapjai is létrejöttek. A felismerhető tendencia tehát:

- hosszabb távon számolni kell a Föld népességének (és ezzel energiaigényének) növekedésével is;

- a növekvő energiaigény kielégítésében fontos szerepe lesz a lokális energiatermelésnek.

- megnő a szén-dioxid megkötésében fontos fotoszintézis-alapú energiahordozók előállításának és az emberiség élelmiszer-ellátását szolgáló biomassza-termelésnek a szerepe;
\end{abstract}


- el kell érni, hogy az élelmiszer-termelés és az emberi lét kommunális folyamatai (élelmiszertermelés, életfolyamatok stb.) primer, szekunder és tercier biomasszáinak minél nagyobb része hasznosuljon a fosszilis energiahordozókat kiváltó energiatermelésben;

- létfontosságú, hogy a biomasszák energetikai hasznosításával a hulladékok környezetkárosító hatását csökkentő vagy megszüntető hatása is érvényesüljön;

- növekedjen az erre alkalmas vagy másra nem hasznosított területeken vagy technológiákban az energetikai célra hasznosítandó primer biomasszák termesztése (energiaültetvények stb.), ami a légkör $\mathrm{CO}_{2}$-tartalmának csökkenését is eredményezi.

\section{ABSTRACT}

The qualitative and quantitative characteristics of the usage of biological energy sources and their changes can be described through trends. State and level of development are influenced by natural and social conditions.

Recently, the economic characteristics of energy production were decisive, and economic competition in energy prices was rampant. New fossil fuels (shale gas, oil sands, coal mines, etc.) and the development of their new technologies were expected to reduce or stagnate fossil energy prices. At the same time, as a result of the international political processes and the economic forces that are essentially influencing politics the previously planned decline in the usage of fossil fuels has been missed.

Today, meeting the growing demand for energy not only involves exploring and using new energy sources but also results in significant increase in the carbon-dioxide content of the atmosphere, due to the release of $\mathrm{CO}_{2}$ by the consumption fossil fuels. As a result, climate change and its acceleration is no longer compensated by photosynthesis. Earlier this negative tendency was challenged by political reasons and energetic lobbies, but recent evidence-based scientific results ensued climate change to be recognized by international political forces.

The main reason for the energy utilization of biomass (the depletion of fossil fuel reserves) has not been proven, the price of fossil fuels does not decrease to the extent possible, its resources are expanding in the medium term, but at the same time, the recognition of the expected impacts of climate change has resulted in unprecedented collaboration of international organizations. Substantive agreements have been reached to reduce $\mathrm{CO}_{2}$ emissions and the use of fossil fuels, the deadlines for enforcement are closer than ever, and the imposition of sanctions of non-compliance can also be considered. This shed a new light on bioenergetics, and the scientific and political foundations of its outstanding development have also been established. The recognizable trends are therefore:

- the long-term growth of Earth's population (and thus its energy demand);

- local energy production plays an important role in satisfying the growing energy demand;

- increase the importance of producing photosynthesis-based natural carbon sinks energy sources and the role of biomass production for human food supply;

- the majority of primary, secondary and tertiary biomasses of food production and communal processes of human existence (food production, biological processes, etc.) should be utilized in the replacement of fossil energy sources;

- it is a prime necessity that the energy utilization of biomasses also affect reduction or elimination the environmental impact of wastes;

- increase the production of primary biomass for energy use (energy crops, etc.) in suitable or unutilised areas or technologies which also results in a decrease in the $\mathrm{CO}_{2}$ content of the atmosphere. 
Kulcsszavak: bioenergetika, biogáztermelés, biológiai energiahordozók, fotoszintézis, elsődleges biomassza, másodlagos biomassza, harmadlagos biomassza

Keywords: bioenergetics, biogas production, biological energy sources, photosynthesis, primary biomass, secondary biomass, tertiary biomass

A bioenergetika a földtörténet újabb korszakában az energetika fontos része lett, és a szénbázisú életforma megjelenésével, majd kiterjedésével vált a földi lét meghatározójává. A bioenergetikában az energiaforrás a Nap, a természeti folyamat a fotoszintézis, amelynek során a napenergia az asszimiláló növényi sejtek kémiai folyamataiban a légkörben levő oxidált állapotú szénatomok $\left(\mathrm{CO}_{2}\right)$ redukálásához szükséges, és a folyamatban felhasznált energia a létrejövő szénhidrát-molekulában rögzül.

$$
\mathrm{CO}_{2}+\mathrm{H}_{2} \mathrm{O}+\text { napenergia } \rightarrow\left(\mathrm{CH}_{2}\right) \mathrm{O}+\mathrm{O}_{2}+\mathrm{H}_{2} \mathrm{O}
$$

A létrejött szénhidrát oxidációjával a megkötött energia visszanyerhető:

$$
\left(\mathrm{CH}_{2}\right) \mathrm{O}+\mathrm{O}_{2} \rightarrow \mathrm{CO}_{2}+\mathrm{H}_{2} \mathrm{O}+\text { hőenergia. }
$$

A földi ökoszisztemák fotoszintézissel évente mintegy 1800 milliárd tonna elsődleges energiahordozót hoznak létre (Whittaker, 1975). A Föld felszínére érkező napsugárzás $2,6 \times 10^{24} \mathrm{~J} / \mathrm{é} \mathrm{v}$ energiainputot jelent. Ebböl a fotoszintézist folytató élölények mintegy $2 \%$ hatásfokkal $5,7 \times 10^{21} \mathrm{~J} / \mathrm{é}_{\mathrm{v}}$ energiatartartalmú biomasszát állítanak elő. Ez tekinthető a Földön a fotoszintézisből származó elméleti biomassza-produkciónak. (Magyarország esetében az évi $437 \times 10^{18} \mathrm{~J} / \mathrm{e} v$ napsugárzással - a földi arányokat elfogadva - évente $958 \times 10^{15} \mathrm{~J} / \mathrm{év}=958 \mathrm{PJ}$ energiatartalmú biomassza jön létre.)

A természetes biomassza-produkció célja a földi élet fenntartása. Ez a folyamat az ember jelenléte nélkül is végbemegy, és már az ember megjelenése előtt is zajlott. Ekkor jött létre a sokszínü, a zárt táplálékláncokra épült élet, amelyben az élő szervezetek létrejötte, létfenntartása és az elhalás után a lebomlás (a széndioxid légkörbe visszajutása) teljes harmóniában ment végbe. Ekkor alakult ki a földi légkör, amelyben a fotoszintézis állította be a légkör $\mathrm{CO}_{2}$ - és $\mathrm{O}_{2}$-tartalmát.

Az ember megjelenésével és az egyre növekvő népesség igényeinek kielégítésével, következett be egy sor olyan változás, amelyek egyre nagyobb mértékben hatnak vissza a földi folyamatokra, és vált szükségessé a biológiai energiahordozók (továbbá a napenergia, a vízenergia és a szél) mellett egyre újabb energiahordozók és energiafajták felkutatása és igénybevétele, ezért az energetika szerepe rohamosan növekedett. A folyamatban a fosszilis energiahordozók feltárása, fel- 
használása vált meghatározóvá, aminek következménye a légkör $\mathrm{CO}_{2}$-tartalmának gyors növekedése. A biológiai energiahordozók felhasználásának minőségi és mennyiségi jellemzői és azok változásai trendekkel írhatók le. A fejlődési és fejlettségi szinteket természeti és társadalmi jellemzők befolyásolják.

Korábban az energiatermelés ökonómiai jellemzői voltak a meghatározók, és az energiaárakban megjelenő gazdasági versenyeztetés volt a jellemző. Az utóbbi időszakban a fosszilis energiahordozók újabb változatainak (palagáz, olajhomok, széntelepek stb.) feltárása és új technológiák kifejlesztése következtében a fosszilis eredetü energiák árának csökkenését vagy stagnálását tapasztaljuk. Sok esetben azonban a nemzetközi politikai folyamatok és a politikát alapvetően befolyásoló gazdasági erők hatására a fosszilis energiahordozók felhasználásának tervezett csökkenése elmaradt.

Napjainkra az egyre növekvő energiaigény kielégítése már nemcsak az újabb energiahordozók feltárásával és használatbavételével jár együtt, hanem a fosszilis energiahordozók használata során felszabaduló szén-dioxid hatására a légkör $\mathrm{CO}_{2}$-tartalmának jelentős növekedése is mérhetö. Ezzel a klímaváltozás megindulása, illetve a fotoszintézissel már nem kompenzálódó gyorsulása jár együtt. Korábban ezt a negatív tendenciát politikai okok és energetikai lobbik hatására igyekeztek tagadni, de az utóbbi időben megismert tudományos alapú bizonyítékok alapján bekövetkezhetett az, hogy a klímaváltozást már nemzetközi politikai erők is elismerik. Erre bizonyíték, hogy a párizsi (klímaváltozással kapcsolatos) megállapodást 2017. július végéig már 175 ország írta alá, és a tervezett hatályba léptetését (2020) is korábbra helyezik.

A bioenergetika jellemzőinek és szerepének megítéléséhez célszerü az energiák és energiahordozók légköri karbonforgalom alapján történő összehasonlítása (1. táblázat). Ez alapján megállapítható, hogy a bioenergetikát kivételes tulajdonságok jellemzik. Az energiahordozó keletkezésekor részt vesz a légköri $\mathrm{CO}_{2}$ megkötésében, és az elsődleges biomasszát létrehozó fotoszintézis $\mathrm{O}_{2}$-emisszióval jár együtt. Ez a földi élet alapfeltételeit teremti meg.

A szén-dioxid megkötésével létrejött biomasszabázisú (és nem fosszilis) energianyerési módok esetében $\mathrm{CO}_{2}$-emisszió is bekövetkezik, de $\mathrm{CO}_{2}$-neutrális folyamatban, ugyanakkor velük a fosszilis energiahordozókat váltjuk ki, azaz felhasználásuk a fosszilis energiahordozók felhasználásának csökkentését eredményezi.

A bioenergetikával kapcsolatban további (nemritkán figyelmen kívül hagyott) szempontot is meg kell említeni. Nevezetesen azt, hogy a Földön a természetes biomassza az ember által folytatott energiagazdálkodástól függetlenül is létrejön. A földi népesség egyre növekvő lélekszáma miatt egyre több élelmiszerre van szükség, ennek előállításához pedig egyre több biomassza szükséges, és melléktermékként is egyre több biomassza keletkezik. Ezek az anyagok természetes folyamatban lebomlanak, és $\mathrm{CO}_{2}$-tartalmuk visszajut a légkörbe. Ebböl az következik, hogy a melléktermék és hulladék biomasszák és a szabad elsőleges 
1. táblázat. Az energiák és az energiahordozók szerepe a földi szén- és oxigénforgalomban

\begin{tabular}{|l|l|l|l|l|l|}
\hline & \multicolumn{1}{|c|}{$\begin{array}{c}\text { Energiák, } \\
\text { energiahordozók }\end{array}$} & $\begin{array}{c}\mathrm{CO}_{2}^{-} \\
\text {megkötés }\end{array}$ & $\begin{array}{c}\mathrm{CO}_{2}^{-} \\
\text {emisszió }\end{array}$ & $\begin{array}{c}\mathrm{O}_{2}^{-} \\
\text {emisszió }\end{array}$ & $\begin{array}{c}\mathrm{CO}_{2} \text {-emissszió } \\
\text { kiváltása }\end{array}$ \\
\hline $\begin{array}{l}\text { fosszilis } \\
\text { horgerdozók }\end{array}$ & szén & & & & \\
\hline $\begin{array}{l}\text { elsódleges } \\
\text { és egyéb } \\
\text { biomasszák }\end{array}$ & földgáz & elsődleges & & & \\
\hline $\begin{array}{l}\text { másodlagos } \\
\text { megújuló } \\
\text { energiák }\end{array}$ & szél & & & \\
\hline nap & vízadlagos & & & \\
\hline $\begin{array}{l}\text { alternatív } \\
\text { energiák }\end{array}$ & geotermia & & & \\
\hline
\end{tabular}

biomassza minél nagyobb hányadának energetikai hasznosítása célszerủ és szükséges, mert így további $\mathrm{CO}_{2}$-emissziót eredményezö energiahordozó váltható ki.

A környezeti változások egyre részletesebb megismerését követően az energetika folyamatainak komplex megítélését meghatározó szempontok kerültek elötérbe. Ezek fontossági sorrendben:

- a Föld népességének igen jelentős és hosszú távon is várható növekedése;

- a népességnövekedéshez kapcsolódó fajlagos energiaigény és így az összes energiaigény növekedése;

- a már veszélyes mértékű klímaváltozás okozta károk és a jövőt érintő előnytelen környezeti változások felismerése;

- a tudományos élet, a politikai élet vezetőinek és az egyre több információhoz jutó társadalmi csoportok döntésbefolyásoló szerepének növekedése.

E sokrétű ismeretbővülés hatására a nemzetközi megállapodásokban egyre konkrétabb elöírások jelennek meg, és a trendek hosszú távú célokra alapozott alakítása válik meghatározóvá. Ennek következménye az, hogy a nemzetközi megállapodásokban (párizsi klímamegállapodás) prioritásokként kerültek rögzítésre:

- a $\mathrm{CO}_{2}$ (és más klímagázok) emissziójának jelentős csökkentése; 
- a fosszilis energiahordozók felhasználásának csökkentése, azok megújuló és alternatív energiákkal és energiahordozókkal történő, növekvő mértékü kiváltása;

- az elsődleges biológiai energiahordozók forrásainak növelése, de az élelmezést szolgáló bázisok csökkentése nélkül;

- a nem elsődleges biológiai energiahordozók minél nagyobb mértékü felhasználása, és ezzel a környezet védelme, hulladékmentesítése;

- a megújuló és az alternatív energiák egymást támogató felhasználása;

- a lokális energiatermelés terjesztése, a helyi energiahordozók minél nagyobb mértékü, azaz a nemzeti forrásokat hasznosító eljárások elötérbe helyezése új munkahelyek létrehozásával és az energiafüggőség csökkentésével egy időben.

Ha a bioenergetikai trendek alakulását alapvetően a Föld népességének változása (növekedése) határozza meg (lásd 2. táblázat), természetesnek kell tekintenünk azt, hogy ezzel együtt a szükségletek mennyiségi növekedése következik be, és emellett a komfortigények is növekednek. Ezek együttesen az energiaigény jelentős növekedését eredményezik. Ezt egyelöre kiszámíthatatlan mértékben növeli meg a klímaváltozással kapcsolatos energiaigény növekedése (hütés) és az eddig még nem lakott területek igénybevételével összefüggő fütés/hütés. A népesség növekedésével együtt jár a helyváltoztatás igényeinek növekedése és a létfenntartással összefüggő logisztikai tevékenység növekedése is.

2. táblázat. A Föld népességének változása

\begin{tabular}{|l|c|c|c|c|c|}
\hline \multicolumn{1}{|c|}{ Időszak } & $\begin{array}{c}\text { Időtartam } \\
\text { (év) }\end{array}$ & $\begin{array}{c}\text { Népesség } \\
\text { az időszak } \\
\text { elején } \\
\text { (millió fó) }\end{array}$ & $\begin{array}{c}\text { Népesség } \\
\text { az idószak } \\
\text { végén } \\
\text { (millió fó) }\end{array}$ & $\begin{array}{c}\text { Népesség- } \\
\text { növekedés } \\
\text { (millió fó) }\end{array}$ & $\begin{array}{c}\text { Növekedési } \\
\text { ütem } \\
\text { (ezer fó/év) }\end{array}$ \\
\hline Kr. e. 10 000-7000 & 3000 & 5 & 10 & 5 & 1 \\
\hline Kr. e. 4500-2500 & 2000 & 20 & 40 & 20 & 10 \\
\hline Kr. e. 2500-1000 & 1500 & 40 & 80 & 40 & 26 \\
Krisztus születése & 900 & 160 & 320 & 160 & 177 \\
-900 & 800 & 320 & 600 & 280 & 350 \\
\hline $900-1700$ & 100 & 1200 & 2500 & 1300 & 13000 \\
$1850-1950$ & 30 & 5000 & 7400 & 2400 & 80000 \\
\hline $1985-2015$ & 85 & 7400 & 10500 & 3100 & 36470 \\
\hline 2015-2100 & & & & & \\
\hline
\end{tabular}


A bioenergetika alapanyagául szolgáló anyagokat (energiahordozók) három nagy csoportba soroljuk, azaz megkülönböztetünk elsődleges, másodlagos és harmadlagos biomasszákat.

Az elsődleges (primer) biomasszák a növényi biomasszák, azok amelyek a Nap energiáit hasznosítva a légköri szén-dioxid és a talajból származó víz felhasználásával jönnek létre, és tárolják a megkötött napenergiát mindaddig, amíg valamilyen biológiai, kémiai, termikus vagy egyéb folyamat nem eredményezi annak felszabadulását. Energiahordozóként nagymértékben hasonlítanak a szilárd foszszilis energiahordozókra, de a belölük folyó energiatermelés a fosszilis bázisú energiatermeléshez viszonyítva a földi szénforgalomban alapvetően eltérő:

- A fosszilis energiahordozó hasznosítása (a kötött karbon oxidálása) közben az évmilliókkal korábban megkötött szénböl jön létre szén-dioxid, amely a légkörbe jut, míg a friss biomassza esetében a jelenkori biológiai ciklusban a szén megkötése $\mathrm{O}_{2}$ felszabadulásával jár együtt, majd az energiatermelés az újonnan megkötött karbont alakítja át szén-dioxiddá, ami folyamatosan újra lekötődik ( $\mathrm{CO}_{2}$-neutrális energiatermelés). A megújuló biomasszából keletkezö $\mathrm{CO}_{2}$ tehát nem növeli a légkör $\mathrm{CO}_{2}$-tartalmát.

- Még kellően nem vizsgált az a tény, hogy a lignocellulózok termesztése vagy hasznosítása közben rövidebb-hosszabb idejű karbontárolás is történik (humusz, termék stb.). Például a természetes faanyag szokásos felhasználása (épületek, belsőépítészet stb.) esetében a tömör faanyagokban (és faalapú termékekben) igen hosszú időre marad a szén kötött állapotban. A növénytermesztés esetében a föld alatti gyökérzetben a betakarítást követően a talajban marad a teljes növénytömeg 12-20\%-a, és ebböl, valamint a talajra hulló levélzet és hajtásrészek lebomlásával (a föld alatt oxigéntöl részben elzárva) bonyolult szénvegyületek (humusz) jönnek létre, amelyek a talajkolloidokkal tartós, a víz megkötését segítỏ vegyületeket képeznek, és a szenet hosszú időre megkötve tárolják. Ezek a folyamatok a lignocellulózok termesztése esetében tehát nemcsak a $\mathrm{CO}_{2}$-neutrális energiatermelést, hanem bizonyos mértékben a szén megkötését és a légkör $\mathrm{O}_{2}$-tartalmának növekedését is eredményezik.

Az energetikai célra figyelembe vehető elsődleges biomasszák eredetük szerint lehetnek

- növénytermesztési technológiák melléktermékei:

○ lágy szárú kultúrnövényeink esetében a szár, szalma, maghéj stb.,

○ gyümölcs-/szőlőtermesztés esetében a metszési és selejtezésből származó fás anyagok,

○ erdőgazdálkodásban folyó végvágások, nevelővágások és egészségügyi kitermelések más célra nem használható dendromasszái,

○ a primer fafeldolgozás kezeletlen melléktermékei; 
- növénytermesztési technológiákból származó főtermékek:

o az eredeti célra gazdaságosan nem hasznosítható dendromasszák (kereslet hiánya),

○ túltermelés miatt gazdaságtalanná vált növényi fötermékek (túltermelés),

○ energetikai célra termesztett lágy szárú (például energianád) és fás (sarjaztatásos, újratelepítéses) ültetvények anyaga.

A szilárd biomasszák mindenekelőtt közvetlen elégetéssel, hőtermelésben hasznosíthatók mint

○ egységes tüzifa,

○ energiafa (fütőmüvek és erőmüvek) energiahordozójaként,

o vékonyfa-apríték (nyesedékek, fás energiaültetvények is),

○ szalma bálázva,

o energianád bálázva,

○ mezőgazdasági melléktermékek és faporok faforgácsok brikettálva vagy pelletálva.

Magyarországon korábban több szenes erőművet állítottak át fatüzelésre, illetve szén és biomassza együttégetésére. Ezeket az erőmüveket nagyrészt leállították. Hasonló folyamatok játszódtak le a kisebb hőtermelök (hőközpontok) esetében is, amelyek vagy a korábbi hőigény megszünése (fütőmüvek, borászati üzemek, élelmiszergyártók hőigénye stb.) vagy az országos energetikai átrendeződések (gázkogeneráció gyors elterjedése a távhőszolgáltatásban) miatt váltak gazdaságtalanná. Új energiapolitikai döntések is születtek. A jelenleg érvényes fejlesztési koncepciók szerint a biomassza-bázisú hőtermelők maximális teljesítménye kogenerációban 40 MW, csak hőtermelésben 20 MW lehet.

A biomasszabázis jelenleg még több újabb hőtermelő egység üzemeltetéséhez is rendelkezésre áll, így városainkban a gázbázisú fütőművek kiváltása is indokolt lenne. Kisebb települések esetében 0,5-2,5 MW teljesítményü hőközpontok telepítése lenne célszerü, ahol a kisebb közösségi hőszolgáltató létesítmények mellett olyan höközpontok létesítése indokolt, amelyeknél a biomassza-tüzeléses alaplétesítményt napkollektorral és napelemmel is felszerelik, és ezzel a nyári időszakban környezetkímélö módon lehet a közösségi épületek vagy a rendszerbe kapcsolt lakások hőellátását is megoldani, kihasználva az alapfütőmü fontos alapkapacitásait (például hőtároló).

A technológiai fejlesztések Magyarországon nagyon vegyes hatások között folytak. Bár lassan, de érzékelhetően tudatosult a tény, hogy a klímaváltozás megjelent, illetve egyre intenzívebb, de a biomassza-bázisú energiatermelés fejlődését-elterjedését meghatározó mértékben befolyásolja a téma nem kiterjedt ismertsége (az oktatás hiányosságai), a biomassza-bázisú energiatermelés vita- 
tott társadalmi támogatottsága és a tartós alapanyagbázis bizonytalan ismerete (agrárpolitika), valamint az átgondolt, rendszerszemléletü környezetvédelmi szabályozó rendszer hiánya. A külföldi $\mathrm{K}+\mathrm{F}$-eredmények gyors honosítása még nem ment végbe, és a hazai kutatási eredmények gyakorlatban történő hasznosításához nem alakult ki megfelelö adaptációs rendszer.

A közvéleményben a téma megítélése megrekedt azon az ismereti szinten, hogy a klímaváltozás globális hatások eredménye, és azt a hazai cselekedeteinkkel érdemben nem tudjuk befolyásolni, ezért a biomasszák energetikai hasznosítását egyszerủen ökonómiai kérdésként értékelték (közvetlen gazdasági összevetés más energiákkal), és az alapanyagbázist sem fejlesztették megfelelően. Ugyanakkor az igen sokféle technológiai fejlesztés és az ezekkel kapcsolatos kutatások számos tapasztalat megszerzését is lehetővé tették.

Igen fontos a biomasszák égetéses hasznosításán belül a tüzeléstechnikák fejlesztése. Az ilyen irányú fejlesztések a legkisebb háztartási tüzelőberendezésektől a nagy fütőművi vagy erőmüvi berendezésekig szükségesek. Ma már közismert (sajnos a lakosság és a kisüzemek esetében még alig ismert) az a tüzeléstechnikai alapszabály, amely szerint minden biomassza-tüzelőanyagot mint energiahordozót csak az eltüzeléséhez kifejlesztett berendezésben és megfelelően homogenizálva, optimális nedvességtartalom mellett lehet jó hatásfokkal hőtermeléshez felhasználni. A megfelelő darabolással/aprítással érhető el az alapanyag leghatékonyabb kigázosodása, és a megfelelő nedvességtartalom mellett a legjobb az energetikai hatásfok. (1 kg élőnedves faanyag fütőértéke $8-9 \mathrm{MJ} / \mathrm{kg}$, légszáraz állapotban 17-18 MJ/kg.) A nedves biomassza égetésekor a füstgázokban sok káros anyag is jelen van, és jut a levegöbe.

Az elsődleges biomasszák a jövőben várhatóan a decentralizált hőtermelésben kerülnek hasznosításra.

- Direkt égetés (oxidáció) hőtermeléshez.

A fejlesztések az energiamérleg és a hatásfokjavítás, illetve a környezeti károkozás csökkentésének céljával folynak. A terjedésének üteme a közelmúltban lassult, mert a környezetvédelmi elöírások szigorodása (füstgázokban a finompor-emisszió korlátozása) a tüzelőberendezések fejlesztését teszik szükségessé.

- A biomassza nem közvetlen hőtermelési célú felhasználásához több hagyományos és sok új technológia kapcsolódik. A megoldás lehet a

○ mechanikai kezeléses átalakítás (például sajtolás olajok kinyeréséhez, energetikai tömörítvények [brikett, pellet] előállításához),

○ vegyi átalakítás (biohajtóanyagok vagy adalékok elóállítása stb.),

- termikus átalakítás (frakcionálás, kigázosítás, elgázosítás, lepárlás stb.) gázbázisú hőtermeléshez, motor hajtóanyagául felhasználva, gázturbinákhoz, bioszén elöállításához stb. Az utóbbi időben intenzív fejlesztések folynak pirogázok, piroolajok előállításával kapcsolatban, 
○ biokémiai átalakítás (fermentáció, biogáztermelés) gázbázisú hőtermeléshez, motorok hajtóanyagául felhasználva, gázturbinákhoz stb., illetve bioalkoholok előállítására motorok üzemanyagául illetve hajtóanyag-adalékként),

○ egyéb technológiák.

A felsorolt technológiák fejlesztése folyik, és a várható általános energetikai trendváltozások a folyamatokat gyorsítani fogják.

Az alapanyagbázis változásának tendenciái:

A szilárd elsődleges biomasszák klímavédelmi és gazdasági szempontból is rendkívül fontosak, ezért a várható alapanyagbázis becslése és fejlesztése is fontos. A biomasszabázis a jelenleginél jelentősen több felhasználó kapacitás üzemeltetéséhez rendelkezésre áll, de pontos felmérése és ezzel megismerése még nem történt meg. A jövőre vonatkozó, megalapozó kutatási eredményként kell figyelembe venni a csapadékra és a hőmérsékletre vonatkozó prognózisokat. Ezeket figyelembe véve a klímaváltozás várható hatásaként számolni kell a hagyományos növénytermesztés produktumának csökkenésével, az erdők hozamának csökkenésével és egészségi állapotuk romlásával.

A növénytermesztés összes hozamának bővítéséhez elkerülhetetlen lesz újabb, melegnek és légköri aszálynak jobban ellenálló fajták nemesítésével, illetve honosításával próbálkozni, valamint az öntözést egyre nagyobb mértékben alkalmazni.

A melléktermék biomasszák kiterjedt hasznosítása mellett feltétlenül szükséges lesz az energetikai ültetvények jelenleginél nagyobb mértékủ terjesztése is (fötermékbázis növelése).

A lágy szárú növényekkel létrehozott ültetvényekhez a gyorsan növő és nagy hozamú növényeket kell alkalmazni. A klímaváltozást is figyelembe véve mindenekelőtt a C4 típusú (magasabb hőmérsékleten is asszimiláló) növények vehetők figyelembe, és célszerủ az öntözésüket is megoldani, elsősorban tisztított szennyvizek és fermentlevek felhasználásával.

A fás energetikai ültetvények a fa-biomassza (dendromassza) előnyös tulajdonságai (kis hamutartalom, alacsony kéntartalom, egyszerü tárolhatóság stb.) miatt változatlanul fontos energiahordozó bázisok maradnak, és a dendromaszsza a decentralizált energiatermelés alapanyagául szolgál (lakossági fütés, mini fütőművek kistelepüléseken stb.). Az energetikai faültetvényekkel kapcsolatos hazai tapasztalatokat és az EU ,zöldítési” programjait figyelembe véve a célültetvények mellett vagy helyett az erdőtelepítést, a nem erdőművelési ágba tartozó fásításokat (fasorok, utak menti fásítások, mezővédő erdősávok stb.) célszerü előnyben részesíteni. Ez azt jelenti, hogy mindenekelött az agroerdészeti technológiákat kell terjeszteni, mert az utóbbi és az EU-ban korszerủnek ismert és támogatott módszerekkel a mezőgazdasági területeken a mikroklíma 
és a vízháztartás javulása, a hagyományos növénytermesztés, illetve a legeltetés hozamainak növelése érhető el. Fásítások és faültetvények létesítése esetében az öt-tizenöt éves vágásfordulóval folyó ültetvényüzemeltetést kell előnyben részesíteni, mert ez a módszer a nem szántóföldi területekre is kiterjeszthető, illetve az ilyen ültetvények mikroklímára gyakorolt hatása is kedvezőbb a minirotációnál. Tapasztalataink alapján megállapítható, hogy a lignocellulózok energetikai célú termesztésekor a technológiákat minden esetben a növénytermesztő és az energetikai felhasználó nagyon szoros és hosszú távú együttmüködésére alapozva kell megvalósítani.

A másodlagos (szekunder) biomassza létrejöttének alapanyagbázisa az elsődleges biomassza, energiaforrása a nem növényi élővilág (állatvilág, rovarok, mikrobák stb.) egyedeiben végbemenő konverziós folyamatokból (táplálkozás) származik, döntően oxidációs folyamatok révén. Vagyis a másodlagos biomassza az elsődleges biomassza átalakítása (táplálkozás) közben fejlődő (állati) szervezetek felépítése során jön létre. A másodlagos biomasszák mint energiahordozók a táplálkozásban töltik be szerepüket, fő zsír- és fehérjeforrások. Szerepük a közvetlen energiatermelésben elhanyagolható, és növekedés a jövőben sem várható.

A harmadlagos (tercier) biomassza az elsődleges és másodlagos biomasszák természetes konverziója során létrejövő, illetve a feldolgozásuk technológiáiból származó anyagok összessége. A legváltozatosabb alapanyagbázis. Az alapanyagok megjelenési formáik szerint lehetnek szilárdak, folyékonyak és gáznemüek. A harmadlagos biomasszák hasznosítását korábban a mezőgazdaság (növénytermesztés) anyagforgalmi rendszerében oldották meg (trágyakiszórás, kiöntözés szántóterületeken). Az új technológiák terjedését hulladékok és melléktermékek mennyiségének rohamos növekedése (iparszerü állattartás, szennyvíztisztítás, települési kommunális hulladékok) és azok környezetvédelmi okok miatt szükséges ártalmatlanítása kényszerítette ki, később a tevékenység elterjedését a megfelelő technológiák által elóállított energiahordozók iránt megjelenő kereslet gyorsította.

A legfontosabb alapanyagok:

- a növénytermesztés más célra nem használható melléktermékei (zöldségtermelés, takarmánytermelés, iparinövény-termesztés melléktermékei/hulladékai),

- az élelmiszergyártás, -feldolgozás, -forgalmazás stb. hulladékai,

- a kommunális technológiák (például szennyvíztisztítás) melléktermékei,

- az állattartás melléktermékei, hulladékai (trágyák stb.).

Ezek az anyagok korlátozott körülmények között vagy speciális technológiák esetében (például: erőművekben szennyvíziszap égetése szénnel keverve, hulladékégetőben hőtermelés) égetéses hőtermeléshez is felhasználhatók. Újabban és meghatározó mértékben a harmadlagos biomasszák energiatermelési célú hasznosítása a biogáztermelés. 
Ezzel a technológiával biogáz $\left(\mathrm{CH}_{4}=30-60 \%, \mathrm{CO}_{2}=65-35 \%\right.$, egyéb $\left.=0-5 \%\right)$ állítható elö. Biogáz előállítása már korábban is folyt, és kezdetben a kommunálishulladék-lerakók megfúrásával kitermelt depóniagázt használtak fel hőtermeléshez, később gázmotorok üzemeltetésére. A közelmúltban a környezetvédelmi nemzetközi megállapodásokban rögzített célok miatt (csökkenteni kell a fosszilis gáz felhasználását) korszerü fermentációs technológiákban a földgázfelhasználás kiváltására növekszik a biogáztermelés. Korábban nagy biogáztelepeket létesítettek, napjainkban kis teljesítményüek (100-500 kW) létesülnek kistelepüléseken és vállalkozások (kisebb húsüzemek, zöldségfeldolgozók, élelmiszerhütők, éttermek, panziók) mellett, mert így az alapanyagok könnyen és gyorsan begyüjthetök, az energia pedig lokálisan hasznosítható. A fermentációs technológia nagy előnye, hogy az alapanyagok sok értékes anyaga a fermentiszap és a fermentlé mezőgazdasági területekre kijuttatásával növényi tápanyagként hasznosul.

A legújabb fejlesztési eredményként lehetőség van a biometán előállítására is. Az új technológiával a biogázból a megfelelő membrános szürővel leválasztják a $\mathrm{CO}_{2}$-ot, és az így nyert, 99\%-ot meghaladó tisztaságú $\mathrm{CH}_{4}$ motorok hajtásához használható, újabban közüzemi hálózatba táplálva gázfogyasztók ellátására használják. Kedvező lehetőségek vannak sűrített gázként tartályokban lokális felhasználóknál történő telepítésre vagy jármüvekre építve a motor (például városi autóbusz) környezetbarát üzemeltetésére is.

A téma összefoglaló értékeléseként megállapítható, hogy a biomassza energetikai hasznosításával kapcsolatban korábban hangoztatott fó indok (a fosszilis energiahordozók készleteinek kimerülése) nem nyert bizonyítást, a fosszilis energiahordozók ára nem csökken, forrásai középtávon bővülnek, ugyanakkor a klímaváltozás várható hatásainak felismerése a nemzetközi szervezetek eddig példátlan összefogását eredményezte. Jelentős, a szén-dioxid-kibocsátás és a foszszilis energiahordozók felhasználásának mérséklésére irányuló megállapodások születtek, amelyek érvényesítésének határidői minden korábbinál közelebbiek, és a vállalt kötelezettségek nem teljesítőinél szankciók alkalmazása is számításba jöhet. Ezzel a bioenergetika új megvilágításba került, és kiemelt fejlesztésének tudományos és politikai alapjai is létrejöttek.

\section{IRODALOM}

Gergely K. - Varró L. (2004): Megújuló energiaforrások Magyarországon - gazdaságossági vizsgálat. Öko. Ökológia, környezetgazdálkodás, társadalom, XII, 1-2.

Marosvölgyi B. (2014): A biomassza energetikai hasznosítása. In: Bai A. (szerk.): A biomassza felhasználása. Budapest: Mezőgazdasági Kiadó

Whittaker, R. H. (1975): Communities and Ecosystems. Macmillan

Whittaker, R. H. (ed.) (1978): Classification of Plant Communities. (Handbook of Vegetation Science) Kluwer Academic Publishers 